\title{
FRACTIONAL RESERVE BANKING: SEBUAH REPRESENTASI EKONOMI SEMU (TINJAUAN EKONOMI ISLAM)
}

\author{
Oleh: Ayief Fathurrahman ${ }^{1}$
}

\begin{abstract}
This article explained that fractional reserve banking is a system full of risks, even threatening the stability of the economy. Its implications led to many phenomena of the crisises, the most obvious example is the occurrence of the great depression in the 1930's. Related to this, Islam considers that fractional reserve banking is a great dengarous system, so that it has been considered contrary to the principles and values which brought by Islam. Concretely Islamic Bank offers a better system with the system profit and loss sharing (PLS). Its implicationis has been very positive, the stability of the economy is relatively bigh and can stimulate the investment climate without the fragile aspects of liquidity, because the 100\% reserve banking is a must.
\end{abstract}

Keywords: fractional reserve, stabiltas, ekonomi Islam.

\section{PENDAHULUAN}

Eksistensi perbankan dalam dunia perekonomian, memang menjadi bagian penting yang tidak bisa dipisahkan dengan kehidupan sosial-ekonomi masyarakat. Dalam perjalanan kehidupan manusia, secara tradisional perbankan sudah difungsikan walaupun masih sangat terbatas dengan segala fungsi dan cakupannya. Namun seiring dengan perkembangan zaman dan tuntutan dinamika kepentingan masyarakat yang mengitarinya, industri perbankan telah mengalami perubahan besar dalam catatan sejarahnya, industri ini menjadi lebih kompetitif karena deregulasi peraturan Saat ini, bank memiliki fleksibilitas pada layanan yang mereka tawarkan, lokasi tempat mereka beroperasi, dan tarif yang mereka bayar untuk simpanan deposan.

Berdasarkan fungsinya, bank sering didefinisikan dengan sebuah lembaga intermediasi keuangan umum yang didirikan dengan kewenangan untuk menerima simpanan uang, meminjamkan uang, dan menerbitkan promes atau yang dikenal sebagai banknote. ${ }^{2}$ John Bouvier, dalam bukunya A Law Dictionary, sebagaimana dikutip dalam Wikipedia, mencoba mendefinisikan kata bank. Menurutnya bank berasal dari bahasa Italiabanca berarti tempat penukaran uang. ${ }^{3}$ Sedangkan menurut Undangundang Negara Republik Indonesia Nomor 10 Tahun 1998 Tanggal 10 November

${ }^{1}$ Staf Pengajar di Fakultas Ekonomi Universitas Muhammadiyah Yogyakarta E-mail: ayief_ospp@yahoo.com.

${ }^{2}$ Hoggson, N. F. Banking Through the Ages, (New York, Dodd, Mead \& Company, 1926)

${ }^{3} J o h n$ Bouvier, A Law Dictionary Sixth Edition 1856, dikutip dari http://id.wikipedia.org /wiki/Bank, tanggal 26 September 2012. 
Ayief Fathurrahman: Fractional Reserve Banking: Sebuah Representasi Ekonomi...

1998 tentang perbankan, yang dimaksud dengan bank adalah badan usaba yang menghimpun dana dari masyarakat dalam bentuk simpanan dan menyalurkannya kepada masyarakat dalam bentuk kredit dan atau bentuk-bentuk lainnya dalam rangka meningkatkan taraf bidup rakyat banyak.

Namun seiring dengan tuntutan zaman dengan segala logika kepentingannya, sistem perbankan sedikit demi sedikit, namun pasti, terus berbenah dan berproses secara evolutif. Semakin meningkatnya ketergantungan masyarakat terhadap eksistensi perbankan mendorong para banker untuk terus meningkatkan sistemnya berbasis teknologi yang canggih, pelayanan yang memanjakan, fasilitas yang memudahkan dan sebagainya. Proses peningkatakan ini tanpa disadari, sedikit demi sedikit telah menggesser garis batas, mereduksi nilai, bahkan mendobrak pintu tatanan moral dan etika peradaban perekonomian umat manusia di seluruh belahan dunia.

Fractional reserve sistem adalah salah satu sistem perbankan modern yang dinilai oleh para ekonom sebagai sumber masalah yang sistemik dan memunculkan crises event. ${ }^{4}$ Sistem ini merangkai kerangka inheren yang tidak stabil karena berasal dari asimetri antara perubahan dalam nilai aset dan perubahan nilai kewajiban. Secara teknis, dengan sistem ini perbankan secara tidak langsung telah memiliki kemampuan untuk menciptakan uang sendiri (creation of money), sehingga dapat diilustrasikan sebagai piramida terbalik yaitu, reserve basic yang lebih kecil malah justru "mendukung" lebih besar jumlah deposito dan kredit. ${ }^{5}$

Akibatnya, tak jarang perbankan menjadibiang krisis perekonomian. Tatanan perekonomian global terus mengalami instabilitas dan merusak pundi-pundi usaha masyarakat dunia, sehingga menciptakan kemiskinan dan pengangguran yang menjadi momok menakutkan bagi setiap orang. Betapa tidak, semenjak sistem perbankan berbasis keserakahan ini mendominasi sistem perekonomian dunia, hampir semua negara pernah mengalami krisis moneter yang menggoyahkan stabilitas negara. ${ }^{6}$ Dalam sejarah ekonomi, krisis

${ }^{4}$ Peristiwa the Great Depression dalam sejarah perekonomian dunia, menjadi penyebab utama (mayor reason) lahirnya pemikiran-pemikiran "baru" dalam rangka penyegaran di area moneter sekaligus menjadi penyumbat celah kemungkinan terjadi kembali peristiwa yang serupa. Salah satunya adalah pemikiran yang diteriakkan oleh para ekonom Chicago, yaitu mereformasi sistem perbankan yang selama ini diberlakukan atas dasar fractional reserve sistem. Baca lebih lanjut Mabid Ali Al-Jarhi, (2004), "Remedy For Banking Crises: What Chicago And Islam Have In Common: A Comment", Islamic Economic Studies Vol. 11, No. 2, March 2004

${ }^{5}$ Valeriano F. García,Vicente Fretes Cibils, dan Rodolfo Maino, (2004), "Remedy For Banking Crises: What Chicago And Islam Have In Common”, Islamic Economic Studies. Vol. 11, No. 2, March 2004, h. 4

${ }^{6}$ Keserakahan telah menjadi akar operasional sistem kapitalis, sehingga pada gilirannya menciptakan tsunami perekonomian masyarakat dunia. Inilah sebetulnya latar belakang mengapa Islam harus "menghidupkan" kembali sistem ekonomi berwawasan Islamic view, agar keseimbangan umat manusia kembali tertata dan berjalan sesuai dengan atura-aturan normal kemanusian. Untuk lebih mendalam baca Mehmet Asutay, "A Political Economy Approach to Islamic Economics: Sistemic Understanding for an Alternative Economic Sistem", Kyoto Bulletin of Islamic Area 
demi krisis ekonomi terus berulang tiada henti, tercatat sejak tahun 1923, tahun 1930, tahun 1940, tahun 1970, tahun 1980, tahun 1990, dan dan tahun $1998-$ 2001, bahkan pada tahun 2008 krisis semakin mengkhawatirkan dengan munculnya krisis finansial di Amerika Serikat, yang memberikan efek domino ke berbagai Negara di penjuru dunia.7 Di dalam bukunya The History of Money From Ancient time to Present Day (1996), Roy Davies dan Glyn Davies menjelaskan dengan jelas kronologi krisis ekonomi dunia secara menyeluruh. Sepanjang Abad 20 telah terjadi lebih 20 kali krisis besar yang melanda banyak negara. Ini berarti, rata-rata setiap 5 tahun terjadi krisis keuangan hebat yang mengakibatkan penderitaan bagi ratusan juta umat manusia. ${ }^{8}$

Dengan demikian, artikel ini mencoba untuk mengkaji secara mendalam mengenai Fractional Reserve Banking, terutama dikaji dari sudut pandang ekonomi Islam. Dalam prakteknya, sistem ini dinilai sarat dengan penipuan dan kebohongan publik yang membahayakan. Untuk itu, mudah-mudahan dengan kumpulan kata dan kalimat yang tertuang dalam artikel ini menjadi sebuah fostulat sebagai basis pendirian bank "baru", memiliki sistem yang tidak bertentangan dengan norma kemanusiaan dan maslahat (falah) sebagaimana yang menjadi tujuan ekonomi Islam.

\section{PERBANKAN DALAM CATATAN SEJARAH}

Dalam kajian historis, sejarah perbankan dimulai dengan adanya bank prototipe pertama dari pedagang pada zaman dunia kuno, yang membuat pinjaman gabah kepada petani dan pedagang yang membawa barang antar kota. Ini dimulai sekitar 2000 SM di Asyurdan Babilonia. Kemudian, di Yunani kuno dan selama Kekaisaran Romawi, pemberi pinjaman yang berbasis di kuil-kuil dan menambahkan dua inovasi penting: diterapkannya deposito dan mengubah uang. Arkeologi dari periode ini di Cina kuno dan India, juga menunjukkan bukti aktivitas meminjamkan uang. ${ }^{9}$

Dalam sejarah Arab pra-Islam, setelah kerajaan Himyar jatuh, jalur-jalur perdagangan didominasi oleh kerajaan Persia dan Romawi. Pusat perdagangan bangsa Arab serentak kemudian beralih ke Makkah. ${ }^{10}$ Makkah disebut sebagai Ummul Quro,

Studies, 1-2(2007), hh. 3-18

${ }^{7}$ Situasi ini dipicu oleh terjadinya kredit macet di sektor properti (subprime mortgage). Sehingga menyebabkan industri sub-prime mortgage skala besar seperti American Home Mortgage Investment Corporation (AHMI), Mortgage Guaranty Insurance Corporation (MGIC), dan New Century Financial Corporation (NCFC), jatuh bangkrut. Para investor kehilangan billiunan dollar untuk mencegah agar aset-aset sub-prime mortgage tidak lenyap. Tindakan ini kemudian memicu terjadinya huru-hara di pasar finansial global. Dikutip dari http://coenpontoh.wordpress.com/ 2007/09/19/efek-domino-krisis-properti-di-as/

${ }^{8}$ Roy Davies and Glyn Davies, (1996), The History of Money From Ancient Time of Present Day, (New York: Oxport University Press), h. 13.

9 "History of Banking", dikutip dari Wikipedia, the free encyclopedia, http:// en.wikipedia.org/wiki/ History of banking

${ }^{10}$ Badri Yatim, Sejarah Peradaban Islam, Dirasah Islamiyah II, Jakarta: PT Raja Grafindo 
Ayief Fathurrahman: Fractional Reserve Banking: Sebuah Representasi Ekonomi...

yaitu sebuah pusat perniagaan besar yang menjadi urat nadi kehidupan masyarakat Makkah. ${ }^{11}$ Pembangunan sektor spritual, keagamaan, dan kebudayaan dibangun di atas prinsip bisnis, jual beli, dan untung rugi. Karena itu, saudagar kaya (kaum kapitalis jahiliah) menjadi orang-orang yang sangat menentukan sekali dalam berbagai hal. ${ }^{12}$ Dari merekalah aturan-aturan hukum dan tradisi yang berlaku dikeluarkan, terutaman dalam kebijakan perekonomian. Secara tidak langsung individu-individu telah melaksanakan praktek perbankan dan fungsinya walaupun masih sangat tradisonal. Praktek perbankan hanya sebatas jasa penitipan harta, kredit, jasa pengiriman uang secara manual, dan ada pula yang memberikan modal kerja. Praktek perbankan individual ini menjadi lahan "basah" bagi kaum kapitalis yang serakah untuk memaksimalkan keuntungan sebesar-besarnya, sehingga sistem bungaberbunga menjadi pilihan. Dari sinilah muncul ketidakadilan, ketimpangan, kerakusan untuk meraup untung sebanyak-banyaknya, yang pada gilirannya menjadikan kaya semakin kaya dan miskin semakin miskin.

Praktek perbankan kemudian berkembang pada masa Islam. Sebagai konsekuensi pemegang peradaban setelah kejayaan Romawi dan Persia, maka aktivitas perekonomian pun sedikit banyaknya bercorak sesuai warna sistem perekonomian peradaban sebelumnya, walaupun telah di-filter berdasarkan hukum Islam. Dalam bukunya Islamic Bank, Sami Hamoud mengatakan bahwa Rasulullah pernah berprofesi layaknya profesi para banker. Profesi ini terbentuk dengan sendirinya, karena Rasulullah dikenal dengan julukan al-Amin, sehingga dipercaya oleh masyarakat Makkah untuk menerima simpanan harta hingga pada saat terakhir sebelum hijrah ke Madinah. ${ }^{13}$

Perbankan mulai berkembang pesat ketika beredar banyak jenis mata uang pada zaman Bani Abbasiyah sehingga perlu keahlian khusus untuk membedakan antara satu mata uang dengan mata uang lainnya. Hal ini dperlukan karena setiap mata uang mempunyai kandungan logam mulia yang berlainan sehingga mempunyai nilai yang berbeda pula. Orang yang mempunyai keahlian khusus ini disebut naqib, sarraf, dan jïbir: ${ }^{14} \mathrm{Aktivitas}$ ekonomi ini merupakan cikal-bakal dari apa yang kita kenal sekarang sebagai praktik penukaran mata uang (money changer). ${ }^{15}$ Bahkan pada

Persada, 2003), h. 14

${ }^{11}$ Karena letaknya geografisnya yang amat strategis, Makkah menjadi tempat persinggahan para kafilah dagang yang datang dan pergi menuju ke kota pusat perniagaan. Di Makkah telah tersedia pasar-pasar sebagai tempat pertukaran barang-barang antar para saudagar dari Asia Tengah, Syam, Yaman, Mesir, India, Irak, Etiopia, Persia dan Romawi. Baca lebih lanjut Abdur Rahman Asy Syarqowi, Muhammad Sang Pembebas: Sebuah Novel Sejarah, diterjemahkan oleh Ilyas Siraj, (Yogyakarta: Mitra Pustaka, 2003), h. 10.

${ }^{12}$ Badri Yatim, Sejarah Peradaban Islam, Dirasah Islamiyah II., h. 11.

${ }^{13}$ Sami Hamoud, Islmic Bank, (London: Arabian Information Ltd, 1985)

${ }^{14}$ Adiwarman A. Karim, Ekonomi Islam Suatu Kajian Kontemporer, (Jakarta: Gema Insani Press, 2001), h. 63.

${ }^{15}$ Sejarah ini terus berlanjut hingga abad dan peradaban setelahnya. Perbankan yang ada di Barat juga berangkat dari aktivitas yang sederhana, yaitu pertukaran uang (Money Changer), 
Ayief Fathurrahman: Fractional Reserve Banking: Sebuah Representasi Ekonomi...

zaman khalifah al-Muqtadir (295-320AH/908-932AC), Dinasti Abbasiyah memiliki pasar sendiri, pasar yang mirip dengan Wall Street di New York dan Lombard Street di London, dan memenuhi semua kebutuhan perbankan perdagangan, industri dan pertanian dalam batasan yang berlaku bahkan memenuhi teknologi lingkungan. ${ }^{16}$

Pada akhir abad ke 16, tepatnya pada tahun 1694, eksistensi bank diperkuat dengan perkembangnya menjadi seperti sebuah firma pada umumnya. Secara historis, perkembangan bank di dunia Barat bermula dari rencana kerajaan Inggris untuk membangun kembali kekuatan armada lautnya untuk bersaing dengan kekuatan armada laut Perancis akan tetapi pemerintahan Inggris saat itu tidak mempunyai kemampuan pendanaan kemudian berdasarkan gagasan William Paterson yang kemudian oleh Charles Montagu direalisasikan dengan membentuk sebuah lembaga intermediasi keuangan yang akhirnya dapat memenuhi dana pembiayaan tersebut hanya dalam waktu dua belas hari. ${ }^{17}$ Bunga sebesar $8 \%$ akan dibayarkan atas pinjaman tersebut, yang dibiayai melalui pembayaran pajak, terutama terhadap bir dan minuman keras lainnya. Pengembalian pokok pinjaman juga akan dilakukan dari pendapatan yang dihasilkannya. Dengan jumlah $£ 1.200 .000$ yang dipinjamkan dalam jangka waktu tertentu, orang-orang yang meminjamkan dana ini akan diberi hak berdasarkan Act of Parliament untuk mendirikan sebuah perusahaan yang disebut The Governor and the company of the Bank of England. ${ }^{18}$

Bank "baru" di atas diperbolehkan untuk menerima deposito uang koin sebagai imbalan karena mengeluarkan tanda terima. Tanda terima ini, pertama kali dikenal sebagai promissory notes dan kemudian sebagai banknotes. ${ }^{19}$ Berdasarkan promissory notes tersebut, Bank of England berjanji untuk membayar sejumlah uang negara atas permintaan pembawanya yang ditentukan pada sisi uang kertas. Sebagai bukti dari jumlah yang dipinjamkan kepada pemerintah oleh Bank, pemerintah mengeluarkan utang jangka panjang (obligasi) yang pada waktu itu dikenal sebagai "stock" atau "fund". ${ }^{20}$ Kemudian usaha perbankan ini berkembang ke Asia Barat oleh para pedagang. Perkembangan perbankan di Asia, Afrika dan Amerika dibawa oleh bangsa Eropa pada saat melakukan penjajahan ke negara jajahannya baik di Asia, Afrika maupun benua Amerika.

Sehingga dalam sejarah perbankan Barat, arti bank dikenal sebagai meja tempat penukaran uang ${ }^{16}$ Duri A.A. (1986), "Baghdad", The Encyclopaedia of Islam (Leiden, E.S. Brill), Vol.1, hh.894909, dalam Umer Chapra dan Tariqullah Khan, Regulation And Supervision Of Islamic Banks, (Jeddah: Islamic Development Bank and Islamic Research And Training Institute, 2000), h. 2.

17 "Sejarah Bank", dikutip dari http://id.wikipedia.org/wiki/Bank, tanggal 26 September 2012

${ }^{18}$ Tarek El-Diwany, The Problem With Interest: Sistem Bunga dan Permasalahannya, diterjemah oleh Amdiar Amir, (Jakarta: Akbar Media Eka Sarana, 2003), hh. 50-51.

${ }^{19}$ Ibid.

${ }^{20}$ Ibid, Dalam kontek ini, sebuah obligasi adalah sebuah dokumen yang diperdagangkan yang mempunyai syarat-syarat pinjaman antara peminjam uang, issuer (yang mengeluarkan) obligasi 
Ayief Fathurrahman: Fractional Reserve Banking: Sebuah Representasi Ekonomi...

Dewasa ini, bank sangat krusial bagi perekonomian masyarakat. Bahkan tak jarang ketergantungan masyarakat terhadap bank sangat menonjol. Hal ini dikaitkan dengan pola struktural kebutuhan masyarakat akan penambahan finansial dalam menjalankan usaha dan atau perekonomian secara luas. Untuk memperoleh pasar serta perluasan usaha perlu ditopang sarana finansial yang memadai. Disinilah pentingnya lembaga keuangan diposisikan guna menopang kegiatan dan kelancaran perekonomian. Dengan berkembangnya teknologi dan cara berfikir yang semakin luas fungsi bank tidak hanya terpaku pada satu tujuan pendanaan secara konvensional tetapi sangat luas perkembanganya.

Namun sayangnya, sarana finansial yang dikembangkan sangat rapuh dan keropos sehingga tak jarang mudah terguncang dengan kondisi perekonomian yang semakin memburuk, bahkan dianggap sebagai sumber tsunami finansial. Sarana finansial hanya ditopang dengan keberadaan aset bank dalam bentuk kepercayaan masyarakat, sehingga sangat penting dijaga guna meningkatkan efisiensi penggunaan bank dan efisiensi intermediasi serta untuk mencegah terjadinya bank runs and panics. Kepercayaan masyarakat sangat penting adanya, karena bank tidak memiliki uang tunai yang cukup untuk membayar kewajiban kepada seluruh nasabahnya sekaligus, karena sistem yang dianut adalah fractional reserve bangking. Sebenarnya disinilah kebobrokan sistem perbankan modern sangat kentara terlihat.

\section{SEKILAS TENTANG FRACTIONAL RESERVE BANKING}

\section{A. Pengertian dan ProsesFractional Reserve Banking}

Fractional Reserve Banking adalah praktek dimana bank mempertahankan hanya sebagian dari simpanan nasabah sebagai cadangan yang tersedia (mata uang atau depositodi bank sentral) sebagai kewajiban untuk pembayaran jika ada penarikan dari nasabah. Sisa dana nasabah lainnya digunakan bank untuk melakukan investasi atau pinjaman (kredit) ke pelanggan lain. Sebagian besar dana ini nantinya dideposito kembali ke bank-bank lain, yang memungkinkan pinjaman lebih lanjut. Jika di dalam sistem moneter jumlah bank yang ada tak terhingga banyaknya, maka proses penyaluran pinjaman tersebut berlanjut dengan akselerasi tanpa henti dan menimbulkan dampak multiplier (multiplier effect). ${ }^{21}$ Inilah awal prosesdi mana uang diciptakan oleh bank-bank komersialdi seluruh dunia.

Selama ini, proses penciptaan uang dilakukan dengan tiga cara; pertama dengan cara mencetak mata uang kertas atau uang logam yang dicetak oleh bank sentral atau yang sering disebut dengan uang kartal, kedua melalui pengadaan utang dan

dan yang telah membeli obligasi tersebut (bondholder.).

${ }^{21}$ Baca lebih lanjut Mandala Manurung dan Prathama Rahardja, Uang, Perbankan, dan Ekonomi Moneter, (Jakarta: Penerbitan FEUI, 2004) h. 22. 
Ayief Fathurrahman: Fractional Reserve Banking: Sebuah Representasi Ekonomi...

pinjaman oleh bank umum yang dizinkan pemerintah ${ }^{22}$, atau sering disebut dengan giral, serta ketiga melalui beragam kebijakan pemerintah, misalnya seperti pelonggaran kuantitatif.

Penciptaan uang melalui bank (BPUG) $)^{23}$ akan menyebabkan jumlah uang beredar bertambah lebih banyak dibanding dengan tambahan deposito itu sendiri. Keberadaan Fractional Reserve Banking di bank-bank komersial di negara-negara Barat dan dunia lainnya adalah sangat tergantung dengan pengawasan dari bank sentral di negara yang bersangkutan. ${ }^{24}$

Bentuk konkrit pengawasan bank sentral adalah diberlakukannya Rasio cadangan yaitu reserve requirement ratio (RRR) atau persyaratan giro wajib minimum (GWM). Ini biasanya berbentuk mata uang fiat yang disimpan dalam lemari besi bank (vault cash), atau di dalam bank sentral. ${ }^{25}$ Sebagai contoh di AS, reserve ratio yang diberlakukan sebesar 10\%, China 16\%, Malaysia 1\%, Pakistan5\% and Switzerland $2.5 \%{ }^{26}$ Jika RRR $=10 \%$, maka dari setiap unit tambahan deposito, sebesar $10 \%$ harus disetor ke bank sentral sebagai GWM. Karenanya, jika sebuah bank umum menerima deposito sebesar Rp100, yang dapat disalurkan sebagai pinjaman adalah Rp90, sedangkan yang harus disetorkan ke bank sentral adalah sebesar Rp10. Dari contoh sederhana ini dapat dikatakan jika RRR makin kecil, maka daya ekspansi kredit bank makin besar, begitu sebaliknya. Inilah yang dimaksud dengan piramida terbalik.

Berkaitan dengan ini, secara teoritis Dornbusch dan kawan-kawan mencoba mengilustrasikannya dengan gambar sebagai berikut: ${ }^{27}$

\footnotetext{
${ }^{22}$ Uang diciptakan di dalam sistem moneter oleh bank-bank pencipta uang giral (BPUG) yaitu bank yang diperbolehkan mengeluarkan chek dan melakukan transaksi kliring (BPR tidak diisinkan mengeluarkan uang giral). Proses penciptaan uang (giral) tersebut bermula ketika deposan menyetorkan dananya di bank. Melalui transaksi ini, bank yang menerima simpanan nasabah dapat menyalurkan simpanan tersebut dalam bentuk kredit kepada debitur. Baca lebih lanjut Mandala Manurung dan Prathama Rahardja, Uang, Perbankan, dan Ekonomi Moneter, (Jakarta: Penerbitan FEUI, 2004) hh. 21-22.

${ }^{23}$ Bank-bank pencipta uang Giral.

${ }^{24}$ Walter Stannres, (2002) "Functions of Central Banks", dikutip dari http:// ideas.repec.org/p/wpa/wuwpma/0201006.html diakses pada 16 September 2012.

${ }^{25}$ Pinar Yesin, (2005), Monetary Macroeconomics, (Zurich: Zurich University Press)

${ }^{26}$ Sani M. Dangulbi, Arfah Salleh, Ahamed Kameel Meera dan A. Aziuddin, (2012), "Fractional Reserve Banking and Maqasid Al-Shariah: An Incompatible Practice?" (May 31, 2012). Available at SSRN: http://ssrn.com/abstract=2071164 atau http://dx.doi.org/10.2139/ ssrn.2071164.

${ }^{27}$ Rudigerd Dombusch, dkk., (2008), Makmokeonomi, (Jakarta: PT Media Global Eduksi), hh. 390-392.
} 


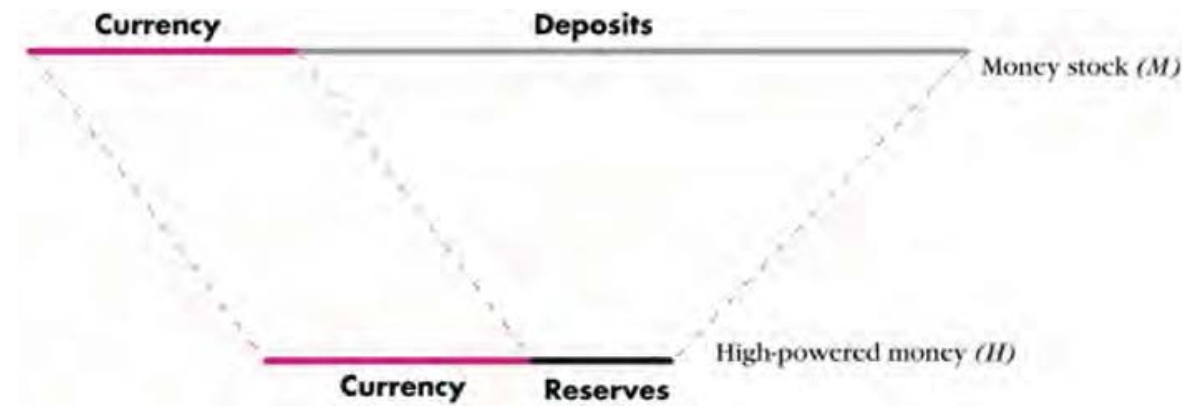

\section{Gambar 1: Hubungan antara Uang berdaya tinggi dan stok uang}

Bank sentral memiliki kontrol langsung pada uang berdaya tinggi (bigh powered money) yang terdiri dari uang karta dan deposito, dengan simbol $H$. Sebagian mata uang dipegang masyarakat membentuk sebagian mata uang yang beredar. Mata uang dalam brankas bank dan deposito bank digunakan bank sentral sebagai cadangan penyokong deposito.Pada gambar di atas diketahui bahwa stok uang berada pada posisi atas, dan stok uang berdaya tinggi berada pada posisi bawah, yang juga disebut sebagai uang primer. Uang dan uang berdaya tinggi dihubungkan oleh pengganda uang. Pengganda uang (Money multiplier) adalah rasio stok uang dengan stok uang berdaya tinggi. Pengganda uang bernilai lebih besar dari 1. Dari diagram jelas bahwa semakin besar deposito sebagai bagian dari stok uang, maka semakin besar -multipliernya. Sebagai contoh, jika rasio cadangan adalah 10\%, maka setiap stok uang rupiah dalam bentuk deposito hanya sebesar $10 \%$ uang berdaya tinggi.

Lebih rinci Dornbusch dan kawan-kawan menjelaskan dengan menggunakan simplifikasi: uang beredar terdiri dari mata uang $(C U)$ ditambah deposit (D):

$$
M=C U+D
$$

Uang berdaya tinggi terdiri dari mata uang ditambah cadangan:

$$
H=C U+\text { Cadangan }
$$

Adapun rangkuman perilaku masyarakat, bank umum, dan bank sentral dalam proses uang beredar paling tidak terdiri dari tiga variabel: currency-deposit ratio (CU/D); reserve ratio (re/D); dan stok uang berdaya tinggi. Persamaa 1 dan 2 menjadi $M=(c u+1) \mathrm{D}$ dan $H=(c u+r e) \mathrm{D}$. Dengan ini dapat dinyatakan uang beredar dalam determinan dasarnya, $r e$, ce, dan $H$ :

$$
M=\frac{1+c u}{r e+c u} \mathrm{H}=m m \times H
$$

Dimana $\mathrm{mm}$ adalah pengganda uang yang dinyatakan dengan:

$$
m m=\frac{1+c u}{r e+c u}
$$


Ayief Fathurrahman: Fractional Reserve Banking: Sebuah Representasi Ekonomi...

Pengganda uang semakin besar ketiak rasio cadangan ( $r e$ ), rasio mata uangdeposito (cu) semakin kecil, sehingga semakin kecil pula proporsi stok uang berdaya tinggi yang digunakan sebagai mata uang.

\section{B. Respon Ekonom terhadapFractional Reserve Banking}

Irving Fischer di dalam karyanya yang berjudul 100\% Money (1935) menyarankan cara pengaturan yang lebih sederhana dan lebih efektif dibanding dengan penggunaan instrument moneter yang ada serta tidak pula menghancurkan kesempatan kerja dan usaha, yakni implementasi rasio cadangan 100\% bagi segenap perbankan. ${ }^{28}$ Kesimpulan penting yang dapat diambil dari buku Fischer adalah bahwa hak perusahaan swasta (bank komersial) untuk menciptkan uang harus dihilangkan dan bahwa negara berdasarkan konstitusi, harus mengambil fungsi secara keseluruhan. Dari sekarang dan selanjutnya, hanya Negara yang mempunyai otoritas untuk menciptakan uang. ${ }^{29} \mathrm{Di}$ dalam pendahuluan bukunya, Fischer menggambarkan bagaimana total uang beredar di AS pada tahun 1929 adalah $\$ 27$ milyar, di mana $\$ 23$ juta merupakan uang giral. Menjelang tahun 1933, total uang beredar telah mengalami kontraksi menjadi \$20 milyar, dimana komponen terbesar kontraksi sebesar \$15 milyar adalah uang giral. Bank-bank komersial telah menghilangkan yang mereka ciptakan sendiri sebesar \$8 milyar, sementara Negara telah mengeluarkan \$1 milyar bagi mata uangnya.

Senada dengan Fisher, Hülsmann dalam tulisannya yang berjudul "Has Fractional-Reserve Banking Really Passed the Market Test?" banyak melontarkan kritikan pedas mengenai dampak fractional reserve banking yang selama ini diterapkan. Menurutnya, sistem ini akan merusakbahasaekonommoneter dananaliskeuangan serta memuntahkan implikasi dan "bola kebingungan" diantaranya:, ketidakseimbangan antara deposito dengan cadangan (reserve) akan mengundang guncangan bahkan krisis moneter yang berkesinambungan (booms and busts). ${ }^{30}$

\section{IV.FRACTIONAL RESERVE BANKING DALAM PERSPEKTIF EKONOMI ISLAM}

Dewasa ini perkembangan sistem perbankan berkembang pesat seirama dengan kepentingan dan dinamika kebutuhan masyarakat yang semakin kompleks. Eksistensi peran perbankan di tengah-tengah masyarakat modern masa kini sangat krusial dan fundamental. Selama ini perbankan dianggap sebagai financial intermediaries yang memiliki fungsi pada tiga hal: pertama, sebagai lembaga yang menghimpun

${ }^{28}$ Irving Fischer, (1935), 100\% Money, (New York: Adelphi).

${ }^{29}$ Ibid.

${ }^{30}$ Jörg Guido Hülsmann, (2003), "Has Fractional-Reserve Banking Really Passed the Market Test?", The Independent Review: A Journal of Political Economy, Vol. VII, No. 3, Winter 2003, pp. 399-422. 
Ayief Fathurrahman: Fractional Reserve Banking: Sebuah Representasi Ekonomi...

dana dari masyarakat dalam bentuk simpanan. Kedua, sebagai lembaga yang menyalurkan dana ke masyarakat dalam bentuk kredit, dan yang ketiga, melancarkan transaksi perdagangan dan peredaran uang. Sayangnya, praktek yang terjadi justru di luar fungsi sebagaimana yang ada. Maksimalisasi profit menjadi alasan bagi perbankan untuk "memaksimalkan" fungsinya walaupun harus ada yang menjadi taruhan.

Dalam rangka mengoptimalkan rangkaian fungsi eksistensi perbankan tersebut, adanya suatu sistem yang memadai dan "menguntungkan" merupakan upaya yang selalu dimaksimalkan, sehingga dapat memberikan kualitas pelayanan yang terbaik kepada masyarakat pada umumnya dan keuntungan yang besar bagi perbankan pada khususnya. Watak komersialisme yang berlebihan nampaknya sudah menjadi detak jantung operasionalisasi sistem yang ada diperbankan, sehingga pada gilirannya, semakin kompleks perkembangan dan tuntutan zaman, semakin tereduksi pula value yang seharusnya mendasari terbangunnya sebuah sistem perbankan.

Proses pengurangan (untuk tidak mengatakan penghapusan) sebuah value sebagai basis kekuatan terbangunnya suatu sistem ini, kini telah menjadi nyata seirama dengan jeratan logika kepentingan kaum kapitalis yang terlepas dari norma dan etika. ${ }^{31}$ Setelah memasuki abad ke-20 ini, sangat nampak begitu jelas bahwa ilmu pengetahuan, teknologi dan sebuah sistem perekonomian terutama sistem perbankan seakan-akan telah menjadi tumpuan harapan manusia dalam menghadapi persoalan hidup walaupun ternyata belum dan tidak akan mampu menyelesaikan persoalan hidup dan kehidupan itu. Hal ini terlihat pada peristiwa-peristiwa yang diamati dalam kehidupan umat manusia dewasa ini yang terperosok ke dalam dilema; antara modernisasi dan ketidakadilan. ${ }^{32}$

Peristiwa the Great Depression pada tahun 1930-an dalam sejarah perekonomian dunia telah membuktikan bahwa sistem yang tidak berkeadilan itu telah menjadi penyebab utama (mayor reason) ambruknya tatanan perekonomian global. Fractional reserve sistem adalah salah satu produk dari sistem yang injustice, dan telah mengundang banyak ekonom dunia untuk merespon kegagalannya sebagai sebuah sistem. Kegagalannya dinilai oleh banyak para ahli bersumber dari kesenjangan yang besar (great gap) antara kucuran kredit dengan simpanan yang seharusnya menjadi cadangan di dalam perbankan.

${ }^{31}$ Dampak yang disumbangkan oleh sistem kapitalisme seperti kemiskinan, kelaparan adalah secuil persoalan mendasar yang masih menghiasi wajah dunia ini. Jeremy Seabrook menuturkan bahwa kemiskinan global bukanlah soal kekurangan sumber daya, melainkan suatu akibat digenggamnya kendali ekonomi oleh negara-negera kaya, baca lebih lanjut Jeremy Seabrook (2006),

Kemiskinan Global: Kegagalan Model Ekonomi Neoliberalisme, (Yogyakarta: Resist Book), h. 69.

32 Juhaya S. Praja, (2000), Filsafat Ilmu: Menelusuri Struktur Filsafat Ilmu dan Ilmu-ilmu Islam, (Bandung:Program Pasca Sarjana Institut Agama Islam Negeri (IAIN) Sunan Gunung Djati), h. 10. 
Ayief Fathurrahman: Fractional Reserve Banking: Sebuah Representasi Ekonomi...

Berangkat dari sistem yang demikian, impelementasi sistem perbankan di berbagai belahan dunia, justru menimbulkan kisah-kisah pilu yang memprihatinkan. Krisis demi krisis telah menghantui masyarakat dunia, dasar perekonomian masyarakat semakin terhimpit. Fractional reserve sistem memang telah menjadi lingkaran sistemik kehancuran perekonomian. Sistem ini dituding oleh berbagai pihak sebagai biang kehancuran yang mengarah pada proses musnahnya hakikat manusia. Salah satunya adalah pemikiran yang diteriakkan oleh para ekonom Chicago, yaitu mendesak untuk mereformasi sistem perbankan yang selama ini diberlakukan.

Manifestasi konkrit dari pemikiran para ekonom Chicago di atas adalah di usulkannya operasional sistem perbankan secara lebih sederhana atau dikenal dengan sebutan "Narrow Bank”. Narrow Bank menawarkan dua manfaat yang signifikan. Pertama, menghilangkan ketidaksesuaian antara kewajiban bankdan aset. Karena ketidaksesuaian tersebut mendorong sistem perbankan untuk bergantung padajaringpengaman yang difasilitasi oleh pemerintah berupa: regulasisuntikan dana (asuransi deposito). Kedua, menghilangkan kebutuhan akan intervesi pemerintah yang besar dalam pinjaman bank dan keputusan kebijakan lain yang jauh melampaui perlindungan sistem pembayaran. ${ }^{33}$

Inilah bukti ketika sebuah sistem sudah tidak lagi di back-up dengan value yang mendasarinya. Nilai-nilai yang adil, etis, dan egaliter, tidak lagi menjadi "ruh" mengembangkan sistem yang ada diperbankan. Tetapi justru nilai-nilai yang individualistik, hedonistik, dan matrealistik yang mendasari derap langkah dalam mencapai tujuannya. Dan jelas, persoalan kemanusiaan yang akan menjadi taruhannya.

Islam memandang bahwa Fractional reserve bankingmerupakan sebuah saluran mafsadat dan sumbernya kemudharatan yang harus segera disumbat dan direformasi, bahkan segera didekontruksi, bukan hanya direkontruksi. Karena tidak sesuai dengan nilai-nilai keadilan dan level keamanan minimal yang diharapkan. Landasan kaidah fiqhiyah "laa dharara wa laa dhirara" (tidak menzalami dan tidak dizalimi)adalah prinsip etis fundamental basis operasional sistem Bank Islam. Di samping itu, Fractional reserve banking jugadianggap sebagai sistem yang merepresentasikan ketidaksesuian -untuk tidak mengatakan kebohongan. Piramida terbalik adalah fenomena yang selama ini terjadi di dalam sistem perbankan, dimana cash reserve ratio yang lebih kecil justru menopang lebih besar jumlah deposito dan kredit.

\footnotetext{
${ }^{33}$ Secara eksplisit, usulan rencana reformasi perbankan tersebut berangkat dari beberapa tujuan, antara lain: (1) memisahkan permintaan dari tabungan, (2) mewajibkan bank untuk menjaga cadangan 100\% terhadap giro dan cadangan 5\% terhadap tabungan nasabah,(3) membentuk Otoritas Moneter Federal (FMA) dengan penuh kontrol atas pasokan mata uang, pembelian dan penjualan sekuritas pemerintah, harga emas, (5) FMA mengambil alih cukup obligasi dari bank-bank untuk menyediakan cadangan $100 \%$ terhadap giro mereka. Baca lebih lanjut Valeriano F. García,Vicente Fretes Cibils, dan Rodolfo Maino, (2004), "Remedy For Banking Crises: What Chicago and Islam Have in Common?", Islamic Economic Studies, Vol. 11, No. 2, March 2004, pp.1-22.
} 
Ayief Fathurrahman: Fractional Reserve Banking: Sebuah Representasi Ekonomi...

Dalam Islam, asas kemanfaatan dan kemaslahatan merupakan tujuan primer yang harus didahulukan. Asas kemanfaatan dan kemaslahatan ini sangat relevan dengan tujuan hukum Islam secara universal. Sebagaimana para filosof Islam di masa lampau seperti al-Ghazali (w.505/1111) dan asy-Syatibi (w 790/1388) merumuskan tujuan hukum Islam (Maqashid syariah) berdasarkan ayat-ayat alQur'an dan al-Hadis untuk mencapai kemaslahatan. ${ }^{34}$ Menurut al-Syatibi, kajian tentang Maqashid syariah ini bertolak dari asumsi bahwa segenap syari'at yang diturunkan Allah senantiasa mengandung kemaslahatan bagi hamba-hamba-Nya untuk masa sekarang (dunia) dan sekaligus masa yang akan datang (akhirat). ${ }^{35}$ Melihat hal itu, Fractional reserve banking tentu sangat bertentangan dengan nilai-nilai yang dibawa Islam. Hubungan asas kemaslahatan dengan Fractional reserve banking barat dua kutub utara yang saling berlawanan. Inilah sumber awal malapetaka perekonomian, ketika sebuah sistem hanya dibangun atas asas kepercayaan. Karena asas kepercayaan bukanlah jangkar yang mengikat, tetapi justru terbangun dari persepsi parsial yang alami dari situasi sosio-ekonomi yang sedang terjadi. Maka ketika kepercayaan itu mulai mengalami ketidakseimbangan, maka ketika itu pula sistem yang dibangun di atasnya mengalami guncangan (contagion).

Krisis saving and loan di Amerika Serikat merupakan salah satu contoh kasus. Tepatnya pada tahun 1980, krisis tersebut mulai mengusik jalannya perekonomian di AS. Guncangan berawal dari keterbatasan sistem keuangan AS, dan ketidaksesuian kontrak simpanan deposito jangka pendek, tetapi deposito-deposito tersebut justru secara simultan dipinjamkan oleh perbankan berdasarkan jangka panjang, sehingga pada gilirannya memunculkan permasalahan krisis likuiditas. ${ }^{36}$

Di samping itu, sistem perbankan yang menerapkan konsep Fractional reserve banking seperti diuraikan di atas, sangat mengandalkan bunga (riba) di dalam operasinya, dan tentu sangat berlawanan dengan prinsip perbankan Islam. Inilah alasan mengapa pihak bank tidak langsung menggunakan uang (cek) yang ia ciptakan, hal ini karena tindakan membelanjakan cek/tanda terima yang diciptakannya secara langsung akan

${ }^{34}$ Yang sering dijadikan contoh dan menjustifikasi ajaran maslahat dari Nabi adalah hadis nabi yang melarang orang-orang Islam di Madinah menyimpan daging kurban, kecuali sekedar bekal selama tiga hari. Beberapa tahun kemudian, ada beberapa orang sahabat yang menyalahi ketentuan Rasulullah Saw. dengan menyimpan daging kurban lebih dari sekedar perbekalan untuk tiga hari. Peristiwa itu disampaikan orang kepada Rasulullah Saw., namun Rasulullah membenarkannya serta menjelaskan bahwa dahulu hal tersebut dilarang karena kepentingan addaffah (para pendatang dari perkampungan badui yang datang ke Madinah yang membutuhkan daging kurban). Ini menunjukkan bahwa ketetapan dari Rasulullah tetap mempertimbangkan kemaslahatan sebagai maqashid syari'ah. Lihat Imam Muslim, (1992), Shobih Muslim, (Beirut: Dar Al-Kutub al-'Ilmiyah), XIII: 110.

35 Al-Syatibi, (1991), al-Muwafaqat fi Ushul al-Syari'ah, Abdullah Darraz (ed),(Beirut: Dar al-Kutub al-'Ilmiyah), hh. 80-91.

${ }^{36}$ Franklin Allen dan Douglas Gale, (1994), "Limited market participation and volatility of asset prices", American Economic Review 84, hh. 933-955. 
mengakibatkan pihak bank kehilangan kepemilikan atas tanda terima tersebut. Kredit merupakan saluran yang lancar bagi perbankan, karena dengan meminjamkan tanda terima (cek) pihak bank bisa membebankan bunga atas jumlah yang dipinjamkan. Ketika proses pembayaran kembali, tanda terima tersebut dapat dengan mudah dimusnahkan, semudah pada saat membuatnya tetapi beban bunga yang dihasilkan akan menjadi bagian pendapatannya. Sehingga dengan demikian, industri perbankan menjadi suatu bentuk usaha yang paling menguntungkan sepanjang masa, karena pihak bank dapat membebankan bunga atas uang yang mereka ciptakan. ${ }^{37}$

\section{BANK ISLAM: SEBUAH SOLUSI KRISIS SOSIO-EKONOMI}

Teori dan konsep Bank Islam berakar dari prinsip-prinsip syariah ${ }^{38}$ yang bertujuan untuk menciptakan kesejahteraan bersama (falab). Oleh karena itu, praktek dan sistem yang diterapkan di Perbankan Islam memuat nilai dan ajaran yang islami. Sistem yang sesuai dengan Islam adalah sistem bagi hasil, dan sistem fractional reserve bangking sangat bertentangan dengan nilai dan prinsip yang diusung oleh Islam. Sehingga fractional reserve bangking tidak pernah diterapkan di perbankan Islam.

Berbeda dengan Bank konvensional, di dalam Bank Islam current account dioperasikan berdasarkan konsep wadi'ah yang memungkinkan pemilik dana dapat menarik dana miliknya sewaktu-waktu. Cash reserve ratio sebesar $100 \%$ akan diterapkan pada rekening tersebut. Dalam konteks ini, perbankan Islam boleh mengambil keuntungan dari service charge yang dibebankan kepada nasabah sebagai biaya administrasi. ${ }^{39}$

Berkaitan dengan current account (wadi'ah) ini, terdapat beberapa pendapat mengenai operasionalnya di perbankan Islam. ${ }^{40}$ Sebagian pakar berpendapat bahwa

${ }^{37}$ Sebagai contoh, pada awalnya, jumlah uang di suatu negara adalah Rp100. Jika pihak bank menciptakan uang sebesar Rp400, maka akan ada total uang beredar sejumlah Rp500. Kemudian Rp400 uang bank dipinjamkan selama tiga tahun dibebankan bunga sebesar $10 \%$ per tahun. Karena itu, jumlah uang beredar akan menjadi Rp532.40 pada saat jatuh tempo untuk pembayaran kembali. Dengan demikian, terdapat selisih Rp32.40. Baca lebih lanjut Tarek ElDiwany, (2003), The Problem With Interest: Sistem Bunga dan Permasalahannya, diterjemahkan oleh Amdiar Amir, (Jakarta: Akbar Media Eka Sarana), h. 49.

${ }^{38}$ Syariah atau syariat menurut bahasa berarti jalan. Syariat adalah jalan dalam agama. Menurut Istilah: Syariat adalah hukum - hukum yang diadakan oleh Allah untuk umat-Nya yang dibawa oleh salah seorang nabi-Nya (Muhamad SAW), baik hukum - hukum yang berhubungan dengan kepercayaan (bidang Aqidah) maupun hukum yang berhubungan dengan amalliyah. Baca lebih mendalam Abdullah Kelib dan Muzamil M.Mawardi, (1982), Asas-Asas Hukum Islam, (Semarang.: Fakultas Hukum Universitas Diponegoro).

${ }^{39}$ Tarek El-Diwany, (2003), The Problem With Interest..., h. 207.

${ }^{40}$ Dilihat dari segi akadnya ada beberapa bentuk wadi'ah yaitu: Pertama, wadiah yad amanah adalah akad penitipan barang/uang dimana penerima titipan tidak diperkenankan menggunakan barang/uang yang dititipkan dan tidak bertanggung jawab atas kerusakan atau kehilangan barang/uang titipan yang bukan di akibatkan perbuatan atau kelalaian penerima 
Ayief Fathurrahman: Fractional Reserve Banking: Sebuah Representasi Ekonomi...

deposito berdasarkan current account dapat digunakan oleh bank untuk memberikan pinjaman bebas bunga, meskipun di dalam pelaksanaannya harus dilakukan dengan seizin pemilik dana. Namun yang harus digarisbawahi adalah adanya, paling tidak, 2 batasan penting pada jenis rekening wadiah ini. Pertama, deposito harus tersedia untuk penarikan segera hanya jika kondisi likuiditas memadai, dan kedua, setiap manfaat atau resiko yang timbul dari peminjaman dana-dana ini akan ditanggung oleh penyimpan. Dengan cara seperti ini, bahaya dalam sistem ekonomi yang telah dibahas sebelumnya, yaitu ancaman dari fractional reserve banking tidak akan timbul. ${ }^{41}$

Menurut Muhammad Nejatullah Siddiqi, secara prinsip, perbankan islam memiliki fungsi sangat sederhana dan sangat tradisionalis ${ }^{42}$ jika dibandingkan dengan fungsi perbankan konvensional, walaupun seiring dengan perkembangan zaman dan pertimbangan maslahat, tidak menutup kemungkinan operasional perbankan Islam akan terus berkembang. Fungsi tersebut layaknya fungsi bank pada umumnya yang sering dimuat dalam definsi perbankan, yaitu sebagai financial intermediaries yang bertugas untuk menghimpun dana dari masyarakat dalam bentuk simpanan dan menyalurkannya kepada masyarakat. Hanya saja metode lending berbeda dengan sistem yang ada di perbankan konvensional, Asas kemitraan (partnership) dipilih sebagai dasar operasional perbankan Islam, sehingga posisi pihak bank dan nasabah bukan bergaris vertikal tetapi horizontal.

Secara lebih rinci, perbankan islam dikenal dengan interest free banking dan memiliki sistem yang dibangun untuk membiayai kegiatan usaha yang sebagian besar didasarkan padapembagian keuntungan-rugi (Profit Loss Sharing), yaitu berupa mode Mudarabah (kemitraan pasif) dan musharakah (kemitraan aktif). Tangguhan perdagangan (murabahah) dan pinjaman bebas bunga (qurûdh hasanab) juga digunakan untuk membiayai konsumen serta transaksi bisnis. Dalan catatan sejarah peradaban Islam, sistem tersebut bekerja cukup efektif selama peradaban Islam dan selama berabad-abad setelahnya. Menurut Udovitch sebagaimana dikutip oleh Chapra dan Tariqullah, mode pembiayaan(mudarabah dan musharakah) mampu memobilisasi "entire reservoir of monetary resources of the medieval Islamic world" (waduk seluruh sumber daya moneter dunia Islam abad pertengahan) untuk pembiayaan pertanian, kerajinan,

titipan. Kedua, wadiah yad dhamanah adalah akad penitipan barang/uang dimana pihak penerima titipan dengan atau tanpa izin pemilik barang/uang dapat memanfaatkan barang/uang dan harus bertanggung jawab atas kehilangan atau kerusakan barang/uang titipan. Baca lebih lanjut H.A. Djazuli, dan Yadi Janwari, (2002), Lembaga Lembaga Perekonomian Umat (Sebuah Pengenalan), (Jakarta: PT. Raja Grafindo Persada), h. 65.

${ }^{41}$ Tarek El-Diwany, (2003), The Problem With Interest..., h. 208.

${ }^{42}$ Fungsi ini dianggap lebih terkontrol dibanding sistem perbankan konvensional yang sudah "liar" bahkan tidak terkendali. Baca lebih lanjut Muhammad Nejatullah Siddiqi, (1998), "Islamic Banks: Concept, Precept and Prospects", Journal of King Abdulaziz University: Islamic Economics, Vol. 10, 1419/1998, hh. 43-59.

${ }^{43}$ M. Umer Chapra dan Tariqullah Khan, (2000), Regulation And Supervision Of Islamic 
manufaktur dan perdagangan lintas regional. Mode-mode tersebut tidak hanya digunakan oleh Muslim tetapi juga oleh orang orang Yahudi dan Kristen. ${ }^{43}$

Berkaitan dengan konteks diatas perlu kiranya untuk digarisbawahi bahwa dibangunnya sebuah sistem didasarkan pada ajaran Islam dan tujuan sosial-ekonomi Islam. Fitur bank Islam harus memiliki pola preferensi yang berhubungan dengan berbagai modus pembiayaan yang diperbolehkan syariah. Paling tidak terdapat dua tujuan yang harus menjadi bencmark, pertama, tujuan finansial yaitu tujuan umum aktivitas ekonomi untuk mendapatkan profit dan benefit dalam skala wajar. Kedua, adalah tujuan sosial, yaitu tujuan yang berbasis nilai-nilai kemanusiaan dan solidaritas kepada sesama. Dari kedua tujuan tersebut, diharapkan terjadinya keseimbangan di dalam roda perekonomian.

Di samping itu, penalaran yang digunakan sebagaimana contoh berikut: sistem bunga dilarang oleh Islam karena hakekatnya merupakan sistem yang sangat tidak adil. Adapun fitur yang membuat sistem bunga menjadi tidak adil adalah bahwa penyedia modal dana terjamin secara tetap (fixed) sedangkan risiko ditanggung oleh pengguna dana modal. Keadilan merupakan ciri dari sistem Islam dan merupakan tuntutan bahwa penyedia dana modal harus berbagi risiko dengan pengusaha jika ia ingin mendapatkan keuntungan.

Berdasarkan dengan konsekuensi mode-mode yang dikembangkan di perbankan Islam, dibawah ini akan dijelaskan secara singkat dampak positif model transaksi islami terhadap perkembangan sosio-ekonomi. Untuk lebih jelas dapat dilihat dibawah ini: ${ }^{44}$

\section{Pengaruhnya terhadap Saving dan Investasi}

Sistem free-interest banking, dalam kondisi tertentu, dapat menyebabkan peningkatan tingkat tabungan, karena dana yang tersimpan relatif aman sesuai dengan minat penabung. Selain itu, pembiyaan berbasis PLS dapat menguntungkan pada tingkat investasi. Secara riil diketahui bahwa permintaan untuk dana investasi dan penyediaan dana investasi pada perbankan berbasis PLS cenderungmenunjukkan peningkatankonsekuen jika dibanding dengan perbankanyang berbasis bunga. Hal ini karena tidak diperlukan lagi biaya tetap yang diperlukan oleh peminjam (baca: perusahaan) yang harus dipenuhi kepada perbankan untuk mengurangi keuntungan perusahaan.

Banks, (Jeddah: Islamic Development Bank and Islamic Research And Training Institute), hh. 1415.

${ }^{44}$ Ziauddin Ahmad, (1994), Islamic Banking: State of The Art, (Jeddah: Islamic Research And Training Institute Islamic Development Bank), hh. 25-28. 
Ayief Fathurrahman: Fractional Reserve Banking: Sebuah Representasi Ekonomi...

\section{Pengaruhnya terhadap Pertumbuhan Ekonomi}

Semakin meningginya iklim investasi maka semakin memberikan prediksi positif bagi pertumbuhan sektor perekonomian. Meningkatnya ketersediaan modal di bawah sistem PLS akan mempromosikan inovasi teknologi dan eksperimen yang akan menjadi faktor plus lain untuk pertumbuhan. Bank syariah juga diharapkan dapat mempengaruhi pola pertumbuhan melalui selektivitas yang tepatdalam operasi keuangannya untuk memastikan bahwa proses pertumbuhan tujuan sosio-ekonomi Islam betul-betul diupayakan.

\section{Pengaruhnya terhadap Efisiensi Alokasi}

Ekonom muslim menyatakan bahwa sistem keuangan berdasarkan kerangka PLS akan lebih efisien dalam mengalokasikan sumber daya dibandingkan dengan sistem konvensional yang berbasis bunga. Posisi ini dipertahankan atas dasar proposisi umum bahwa setiap perkembangan keuangan yang menyebabkan alternatif investasi dan akan dibandingkan dengan satu sama lain, benar-benar didasarkan pada produktivitas dan tingkat pendapatan, sehingga pada akhirnya akan menghasilkan perbaikan alokatif.

\section{Pengaruhnya terhadap Stabilitas Sistem Perbankan}

Dalam sistem interest-based, nilai nominal kewajiban deposito tetap. Namun, tidak ada jaminan di sisi aktiva bahwa semua kredit yang diberikan akan pulih. Guncanganpada sisiaset, karena itu akan menyebabkan perbedaan antara aset dan kewajiban (fractional reserve banking), dan sistem perbankan dapat mengalami proses hilangnya kepercayaan, yang pada akhirnya pasti menyebabkan perbankan masuk ke dalam lingkaran krisis likuiditas. Dalam sistem berbasis PLS, nilai nominal deposito investasi tidak dijamin, dan guncangan terhadap posisi aset segera diserap dalam nilai deposito investasi. Ini meminimalkan risiko kegagalan bank dan meningkatkan stabilitas sistem perbankan

\section{Pengaruhnya terhadap Stabilitas Perekonomian}

Sudah menjadi pengetahuan umum bahwa pembiayaan utang berbasis bunga merupakan faktor utama dalam menyebabkan ketidakstabilan ekonomidi negaranegara kapitalis. Sangat mudah disaksikan, misalnya, bagaimana' Sistem berdasarkan bunga mengintensifkan resesi bisnis, setelah diketahui bahwa bank mulai mengalami kerugian, pihak bank pasti akan mengurangi bantuan dan menelepon kembali pinjaman, sehingga pada akhirnya beberapa perusahaan harus gulung tikar. Akibatnya pengangguran meningkatdan berimbas pada pengurangan daya beli masyarakat. Di sisi lain, Bank-bank Islam, siapuntuk berbagi jika mengalami kerugian sehingga bisa mengurangi keparahan resesi bisnis dan memungkinkan usaha produktif untuk bertahans elama periode sulit tanpa di-shut down. Oleh karena itu Perbankan Islam dianggap sebagai promotor stabilitas daripadas aluran ketidakstabilan 
Ayief Fathurrahman: Fractional Reserve Banking: Sebuah Representasi Ekonomi...

Untuk itu peran Islam dalam pengembangan sistem perekonomian secara umum dan sistem perbankan secara khusus tidak bisa tidak, memang menjadi sebuah keharusan. Perannya sebagai "obat" yang menyembuhkan dari sebuah gejala "overdoses" yang bisa mematikan.

\section{PENUTUP}

Dari penjelasan di atas dapat disimpulkan bahwa Fractional reserve banking merupakan sistem yang sarat akan resiko, bahkan menafikan aspek kemaslahatan yang mengancam stabilitas perekonomian. Implikasi dari sistem ini menyebabkan banyak fenomena krisis, contoh yang paling jelas adalah terjadinya the great depression pada tahun 1930-an. Berkaitan dengan itu, Islam memandang bahwa Fractional reserve banking merupakan sistem yang mengandung komposisi kemudharatan yang besar, sehingga dinilai bertentangan dengan prinsip dan value yang dibawa oleh Islam. Bank Islam secara kongkrit menawarkan sistem yang sangat bumanis dengan sistem profit and loss sharing (PLS). Implikasinya sangat positif, stabilitas perekonomian relatif stabil dan dapat merangsang iklim investasi tanpa merapuhkan aspek likuiditas perbankan, karena reserve 100\% yang ada di perbankan menjadi sebuah keharusan.

\section{DAFTAR PUSTAKA}

Ahmad, Ziauddin (1994), Islamic Banking: State of The Art. Jeddah: Islamic Research and Training Institute Islamic Development Bank.

Al-Jarhi, Mabid Ali (2004), "Remedy For Banking Crises: What Chicago And Islam Have In Common: A Comment", Islamic Economic Studies Vol. 11, No. 2, March 2004, pp. 23-42.

Allen, Franklin dan Douglas Gale (1994), "Limited market participation and volatility of asset prices", American Economic Review 84, hh. 933-955.

Al-Syatibi (1991), al-Muwafaqat fi Ushul al-Syari'ah,Abdullah Darraz (ed). Beirut: Dar al-Kutub al-'Ilmiyah.

Anonim (a), History of banking, dikutip dari Wikipedia, the free encyclopedia, http:/ Len.wikipedia.org/wiki/ History of banking diakses tanggal 26 September 2012.

Anonim (b), Sejarah Bank, dikutip dari http://id.wikipedia.org/wiki/Bank, diakses tanggal 26 September 2012.

Asutay, Mehmet. (2007). "A Political Economy Approach to Islamic Economics: Systemic Understanding for an Alternative Economic System". Kyoto Bulletin of Islamic Area Studies 1(2): 3-18. 
Ayief Fathurrahman: Fractional Reserve Banking: Sebuah Representasi Ekonomi...

Asy Syarqowi, Abdur Rahman (2003), Muhammad Sang Pembebas: Sebuah Novel Sejarah, diterjemahkan oleh Ilyas Siraj. Yogyakarta: Mitra Pustaka.

Chapra, M. Umer dan Tariqullah Khan (2000), Regulation And Supervision Of Islamic Banks. Jeddah: Islamic Development Bank and Islamic Research And Training Institute.

Dangulbi, Sani M., Salleh, Arfah, Meera, Ahamed Kameel and Aziuddin, A. (2012), "Fractional Reserve Banking and Maqasid Al-Shariah: An Incompatible Practice?" (May 31, 2012). Available at SSRN: http:/ /ssrn.com/abstract $=2071164$ atau http://dx.doi.org/10.2139/ ssrn.2071164.

Davies, Roy and Glyn Davies, (1996), The History of Money From Ancient Time of Present Day. New York: Oxport University Press.

Diwany, Tarek (2003), The Problem With Interest: Sistem Bunga dan Permasalahannya, diterjemah oleh Amdiar Amir. Jakarta, Akbar Media Eka Sarana.

Djazuli, H.A., dan Yadi Janwari (2002), Lembaga Lembaga Perekonomian Umat (Sebuah Pengenalan. Jakarta: PT. Raja Grafindo Persada.

Dornbusch, Rudigerd, et.al. (2008), Makroekonomi. Jakarta: PT Media Global Eduksi.

Fischer, Irving (1935), 100\% Money. New York: Adelphi.

García, Valeriano F. , Vicente Fretes Cibils, dan Rodolfo Maino (2004), "Remedy For Banking Crises: What Chicago And Islam Have In Common”, Islamic Economic Studies. Vol. 11, No. 2, March 2004.

Hamoud, Sami (1985), Islamic Bank. London: Arabian Information Ltd.

Hoggson, N. F. (1926), Banking Through the Ages. New York: Dodd, Mead \& Company.

Hülsmann, Jörg Guido (2003), "Has Fractional-Reserve Banking Really Passed the Market Test?", The Independent Review: A Journal of Political Economy, Vol. VII, No. 3, Winter 2003, pp. 392-422.

Karim, Adiwarman A. (2001), Ekonomi Islam Suatu Kajian Kontemporer. Jakarta: Gema Insani Press.

Kelib, Abdullah dan Muzamil M.Mawardi (1982), Asas-asas Hukum Islam. Semarang: Fakultas Hukum Universitas Diponegoro.

Manurung, Mandala dan Prathama Rahardja (2004), Uang, Perbankan, dan Ekonomi Moneter. Jakarta: Penerbitan FE UI. 
Ayief Fathurrahman: Fractional Reserve Banking: Sebuah Representasi Ekonomi...

Muslim, Imam, Shohih Muslim. Beirut: Dar Al-Kutub al-'Ilmiyah.

Praja, Juhaya S. (2000), Filsafat Ilmu: Menelusuri Struktur Filsafat Ilmu dan Ilmu-ilmu Islam. Bandung:Program Pasca Sarjana Institut Agama Islam Negeri (IAIN) Sunan Gunung Djati.

Seabrook, Jeremy (2006), Kemiskinan Global: Kegagalan Model Ekonomi Neoliberalisme. Yogyakarta: Resist Book.

Siddiqi, Muhammad Nejatullah (1998), "Islamic Banks: Concept, Precept And Prospects", Journal of King Abdulaziz University: Islamic Economics, Vol. $10,1419 / 1998$.

Stannres, Walter (2002), "Functions of Central Banks", dikutip dari http:// ideas.repec.org/p/wpa/wuwpma/0201006.html diakses pada 16 September 2012.

Yatim, Badri (2003), Sejarah Peradaban Islam, Dirasah Islamiyah II. Jakarta: PT Raja Grafindo Persada.

Yesin, Pinar (2005), Monetary Macroeconomics. Zurich University Press. 